\title{
The Impact of Private Food Standards on Developing Countries' Export Performance: An Analysis of Asparagus Firms in Peru
}

\author{
MONICA SCHUSTER and MIET MAERTENS* \\ KU Leuven, Belgium
}

\begin{abstract}
Summary. - In this paper we analyze the impact of private food standards on the export performance of asparagus export firms in Peru. We use 18-year panel data from 87 firms and apply fixed effects and GMM models. We do not find any evidence that certification to private standards in general and to specific individual private standards, has an effect on firms' export performance, neither at the extensive margin nor at the intensive margin, and neither on export volumes nor on export values. Our case-study results imply that private standards do not act as a catalyst to trade.

(c) 2014 Elsevier Ltd. All rights reserved.
\end{abstract}

Key words — food standards, high-value exports, global value chains, trade effects, Peru

\section{INTRODUCTION}

In recent decades, international trade in agricultural and food products has experienced an important shift from being regulated by traditional market access barriers, such as tariffs and quotas, toward being governed by a variety of public and private standards related to product characteristics and production, processing, and distribution procedures (Hoekman \& Nicita, 2011). Public standards are set by public authorities, and usually deal with food quality and safety issues. They are mostly mandatory, controlled through official inspections and enforced by law. Private standards are set by private companies and non-state actors, and often deal with ethical and environmental concerns in addition to food quality and safety issues. They are de jure voluntary - but are sometimes argued to be de facto mandatory if a large share of buyers requires compliance - controlled through private audits and enforced through third-party certification (Henson \& Humphrey, 2010).

The increased use of standards has implications for food trade but it is unclear whether food standards stimulate or impede trade. This question is specifically important when developing countries' food exports are concerned. First, buyers in high-income markets might be more inclined to require compliance with private standards when sourcing from developing countries. Asymmetric information problems are more severe in trade relations between industrialized and developing countries than in trade between similar regions (with similar norms about food safety and quality), which may cause private standards to be more important for developing countries' exports (Jaffee \& Henson, 2004).

Second, agricultural and food exports are a fundamental component of developing countries' growth and entail the potential to reduce rural poverty. This makes the current debate on whether food standards act as non-tariff barriers to trade or as catalysts to trade for developing countries particularly important (Jaffee \& Henson, 2004; Maertens \& Swinnen, 2007). On the one hand, compliance with standards requires one-time investments, e.g., to update facilities, and recurrent fixed costs, e.g., for certification procedures (Maskus, Otsuki, \& Wilson, 2013). For exporters and farmers in developing countries, these costs may be high relative to their operational size and financial means. Also the lack of government investments in food safety capacity in developing countries and the wide divergence between implicit norms on food quality and safety in these countries and standards in export markets may result in high compliance costs for farmers and exporters. By increasing the cost of trade, standards may act as barriers to trade and especially limit exports from developing countries. On the other hand, standards can solve information asymmetries between trading partners and reduce transaction costs, and act as catalysts to trade (Hudson \& Jones, 2003; Jaffee \& Masakure, 2005).

In a review on how food standards affect developing countries' exports, Honda, Otsuki, and Wilson (in press, Ch. 7) indicate that, while there is an increasing number of empirical studies on this issue from varying sectors and countries and using varying methods, the evidence is very mixed and there is a need for more empirical evidence to come to more general conclusions.

The aim of this paper is to contribute to the debate with a case-study on how certification to different types of private standards affects the export performance of asparagus companies in Peru. Peru is the largest exporter of fresh asparagus worldwide and its history in asparagus exports dates back to the 1980s. The sector accounts for $25 \%$ of total agro-food exports and yearly involves around 100 export companies. From the early 2000 s private standards started to spread in the sector and by 2011 about half of the export companies are certified to one or several schemes. The large size of the sector, with a large number of companies involved, and the

\footnotetext{
* The authors gratefully acknowledge scholarship funding from the FWO - Research Foundation Flanders. We are thankful to Eric Rendón Schneir and Andrés Casas Díaz from the Universidad Agraria La Molina and Edwin Helar Chumacero Jiménez for much appreciated support in data collection in Peru. We are also indebted to the 94 export companies that agreed to participate in our survey and to SUNAT, Promperu, IPEH, Ruth Rosell from Frío Aereo, Roberto Ramírez Otárola and the Dirección Regional Agraria in Ica and Trujillo. We thank seminar and conference participants in Leuven, San Diego (IATRC annual meeting) and Foz do Iguazu (ICAE triennial conference) for useful comments on earlier versions of the paper. Final revision accepted: August 29, 2014.
} 
recent spread of private standards make it an ideal case-study to analyze the impact of certification to private standards on firms' export performance. We analyze firms' propensity to export, as well as their export volumes and values, thereby distinguishing between effects at the extensive and intensive margin. We take into account the heterogeneity of private standards by analyzing the effect of standards in general and of particular individual standards. We use customs data on exports during 1993-2011, combined with tax administration data and data from an own firm survey. We use OLS, fixed effects and system GMM models to estimate effects and control for export persistence, reverse causality and time-constant unobserved heterogeneity.

The paper is organized as follows. In Section 2 we frame our research in the existing empirical literature, we explain the mechanisms through which standards might affect export performance, and further elucidate the contribution this paper makes in the literature. In Section 3 we describe our database, the Peruvian asparagus export sector and heterogeneity across export firms. In Section 4 we present the econometric strategy to estimate the impact of certification to private standards on firms' export performance. In Section 5, we discuss the results and in Section 6, we conclude with policy and research implications.

\section{PRIVATE STANDARDS AND DEVELOPING COUNTRIES' FOOD EXPORTS}

There is a growing body of empirical literature that analyzes the relationship between standards, both public and private, and trade flows at the import and export level, and feeds the debate on "standards-as-barriers" and "standards-ascatalysts". The largest part of the evidence comes from macro-economic trade models, usually gravity models, that estimate the impact of increasing standards, usually public standards, on international trade flows. This literature generally points to a trade enhancing impact of standards, even if overall results remain ambiguous. Some authors find that standards are a significant source of trade restrictiveness for middle- and low-income countries (e.g., Anders \& Caswell, 2009; Hoekman \& Nicita, 2011; Tran, Wilson, \& Anders, 2012; Wilson, Mann, \& Otsuki, 2003), while others indicate that standards have no impact at all on exports from developing countries (e.g., Xiong \& Beghin, 2013). Another issue in the debate is that standards could be less trade restricting if harmonized into consistent sets of international standards (e.g., Wilson \& Otsuki, 2003; Wilson, Otsuki, \& Majumdar, 2003 and Czubala, Shepherd, \& Wilson, 2009). Two recent studies conclude that the direction and magnitude of effects are sector specific and specific for different types of standards (Melo, Engler, Nahuehual, Cofre, \& Barrena, 2014; Shepherd \& Wilson, 2013).

The empirical evidence from gravity models is very informative in the debate but needs to be complemented with firmlevel evidence to understand micro-economic effects and within-country dynamics (Honda et al., in press, Ch. 7). The recent international trade literature puts a lot of emphasis on export decisions, export performance and export persistence of individual firms (e.g., Bernard \& Jensen, 1997; Roberts \& Tybout, 1997). Melitz (2003) seminal work introduced the concept of firm heterogeneity and self-selection of firms into exporting. Recent empirical studies confirm that observed as well as unobserved heterogeneity in firm characteristics matter to explain trade (e.g., Bernard, Jensen, Redding, \& Schott, 2007; Breinlich \& Criscuolo, 2011;
Helpman, Melitz, \& Rubinstein, 2008). This confirms the need for firm-level studies on trade implications of standards.

Certification to private standards may have several effects at the micro-level. Standards reduce information asymmetries between importers and exporters about quality and production techniques (Darby \& Karni, 1973; Nelson 1970), which may affect firms' economic performance in terms of market shares, efficiency, export volumes, and values. Due to market signaling effects, as well as gains originating from improved internal management and operational monitoring (Graffham, Karehu, \& MacGregor, 2009), certification to standards can increase firms' export volumes. Compliance with standards and certification involves fixed and variable costs that are borne by exporters and that vary considerably across individual firms (Maskus et al., 2013). Firms will decide to become certified if their individual expected utility of certification is higher than the costs they have to bear to adopt a standard. The lower the certification costs or the larger the expected firm benefits, the higher the probability for a firm to seek certification. Heterogeneity in firm characteristics will result in different adoption behavior of companies, with more productive firms self-selecting into standard compliance and certification. This may lead to the reallocation of resources from noncomplying to complying firms (Geroski, Machin, \& Van Reenen, 1993) and a progressive market exit of less productive firms. However, in line with industrial cluster theory, it might well be that certification of several firms creates export benefits for non-certified firms through spillover effects, and benefits the whole sector in addition to the firm individual benefits (Giuliani, Pietrobelli, \& Rabellotti, 2005).

While there are some studies analyzing the impact of standards on the export performance of firms in industrialized countries (e.g., Fontagné, Orefice, Piermartini, \& Rocha, 2013), few empirical studies explore the relations between standards and the export performance of firms in developing countries and even less studies specifically look at the agricultural and food sector. ${ }^{1}$ Volpe-Martincus, Castresana, and Castagnino (2010) and Otsuki (2011) for instance investigate the effect of one specific voluntary standard that applies to different sectors in developing countries and find that ISO certification respectively improves the export performance of firms in Argentina and in Central Asia. Chen, Wilson, and Otsuki (2008) study how public standards in different destination markets affect developing-country firms' export decisions, and find that quality standards are positively correlated with firms' average export volume and with their export scope, measured by the number of export markets and products. To the best of our knowledge, there is only one study that provides firm-level evidence on the impact of private food standards on developing countries' agricultural export performance: Henson, Masakure, and Cranfield (2011) empirically investigate the impact of GlobalGAP certification on the export revenue of fresh produce exporters in ten African countries and conclude that certification improves firms' export revenues.

Our analysis builds on and extends the existing work on private standards and trade with developing countries in four main ways. First, with a new case study on Peruvian asparagus export firms we contribute to the debate, and create insights that are complementary to evidence from macro-economic gravity models and add to the scarce literature on firm-level trade effects of standards. Second, thanks to the size (over 100 export firms per year) and long history of the sector (data from 1993 to 2011) we are able to keep country and sectorspecific characteristics constant. With this single sector and country study we get rid of country and sector heterogeneities 
and complement multiple country (Chen et al., 2008; Henson et al., 2011; Otsuki, 2011) and sector (Volpe-Martincus et al., 2010) studies. Third, with a panel dataset over 18 years, rather than a cross-section or repeated cross-section as in most previous studies, we can control for firm-specific heterogeneities and export dynamics over time. This allows us to integrate insights on the importance of firm heterogeneity from the international trade literature. This is particularly important in the analysis of the effects of private standards, as adherence is voluntary and can depend on unobserved heterogeneity of firms and past export performance. We also complement previous studies by taking individual firms' export persistence into account. Fourth, we focus on all types of voluntary private standards that are present in the Peruvian asparagus export sector and are able to study effects of several individual certification schemes. Fifth, as in Volpe-Martincus et al. (2010) we focus on a middle-income country, where the export sector was already established previous to the rise of private standards and where effects could thus be different from a sector or country where the export sector developed contemporaneously to the rise of private standards.

\section{DATA AND DESCRIPTIVE STATISTICS}

\section{(a) Data}

We use a unique firm level dataset on Peruvian fresh asparagus exports constructed from secondary sources and own original data collection. Secondary data include transaction-level customs data and tax administration data on 567 asparagus export firms for the period 1993-2011. The customs data contain information on the identification of the exporter (firm names and tax identification number), the exported volume, the destination market, and the FOB value for all export transactions. Since virtually the entire asparagus production in Peru is destined for export, the data comprise the entire industry sales. We collapsed the transaction-level data to the yearly level and merged it with tax administration data. The latter contain information on the foundation date of the firms, core activities, general managers, location, branches, as well as historical fiscal benefits or irregularities. In our dataset all companies are considered as "exporters" from the year they first export fresh asparagus and as long as they are registered as an active export company with the tax administration. We substitute zeros with missing values for export volumes and FOB values of the companies considered as "exporters". Tax administration data are available for all years in which the company is registered as being active.

We complement these secondary records with primary data from a survey among a representative sample of export companies. From the total population of 567 firms, that at least once exported fresh asparagus during 1993-2011, we draw a stratified random sample of 100 companies. We randomly selected companies from three mutually exclusive strata, according to the companies' exporting experience in 2011: consolidated companies with at least 6 years of export experience (total population of 63 companies), intermediate companies, with between 3 and 5 years of export experience $(90$ companies) and start-up companies with less than 3 years of experience (416 companies). Together consolidated and intermediate companies are responsible for $88 \%$ of the volumes exported during 1993-2011 and are more likely to be certified to private standards than start-up companies. The latter often only export for a few years and then withdraw from the export sector. For the analysis of how standards affect export performance, consolidated and intermediated companies are more relevant, and, therefore, we oversample these companies. The sample includes both companies that were operational in 2011 , the year the survey was implemented, as well as companies that ceased operations by that year. This sampling strategy ensures that the sample is representative not only for the current situation but for the whole period. The survey was implemented between July and September 2011 using an original questionnaire including recall questions on the certification to private food standards, production and processing procedures, management structure, ownership, etc.

In the subsequent analysis, descriptive statistics are partially drawn from secondary data, including the whole population of 567 companies, and partially from primary data, coming from the sample of $87^{2}$ companies and including 44 consolidated companies, 27 intermediate companies, and 16 start-up companies. In the latter case we use sampling weights that put less weight on consolidated and intermediate companies and more weight on start-up companies to adjust for the stratified sampling design. In particular, we calculated different weights for each year of the analysis according to the number of consolidated, intermediate, and start-up companies that were present in the entire population of export firms and the number of firms that we had included in our sample. Regressions are run on 84 out of the 87 surveyed companies, due to missing values in the company covariates and on 70 companies when lagged variables are used as instruments for current variables.

\section{(b) Export performance}

Peru is the largest exporter of fresh asparagus worldwide. The sector currently accounts for about $25 \%$ of the country's total agricultural exports. More than 220,000 ton of asparagus are produced yearly. There is no domestic market for asparagus and $99 \%$ of the whole production is exported, of which $70 \%$ as fresh produce (SUNAT-customs data, 2011). The main destination market for fresh asparagus exports are the USA and, to a smaller extent, countries in the European Union. The history of cultivation and export of asparagus from Peru goes back to the 1950s, when imported seeds from California (USA) were first planted in La Libertad region in Northern Peru. Production and export did not expand considerably until the mid 1980s, when a project funded by the U.S. Agency for International Development (USAID) brought the seeds to the Ica region, located south of Lima. Following the excellent production results obtained in Ica with USAID assistance, other private firms - mainly with an agricultural investment background-replicated the experience.

Figure 1 shows the evolution of the total export volume and value (Figure 1a), and the number of firms exporting each year (Figure 1b). Asparagus exports increased tremendously in the period 1993-2011, from 4,590 ton and 6.4 million USD in 1993 to 134,992 ton and 286 million USD in 2011 (Figure 1a). Export growth was steady during the 1990s, accelerated in the late 1990s, and slowed down again from 2009 onward. The accelerated growth in the late $1990 \mathrm{~s}$ is due to the introduction of several new neo-liberal land policies and laws promoting private investment in agriculture at the end of the 1990s (Diaz, 2007; O'Brien and Diaz, 2004; Shimizu, 2006). The growth slowdown in 2009 is likely related to increasing USD/Peruvian Nuevo Sol exchange rate fluctuations ${ }^{3}$ and to overall international demand shocks, e.g., the global economic crisis that badly impacted all Peruvian exports. The number of firms exporting each year shows a similar trend (Figure 1b). The number has tripled from around 40 firms at the end of the 1990s to almost 120 firms in 2006, and stabilized 


\section{a) Total export volume and value}

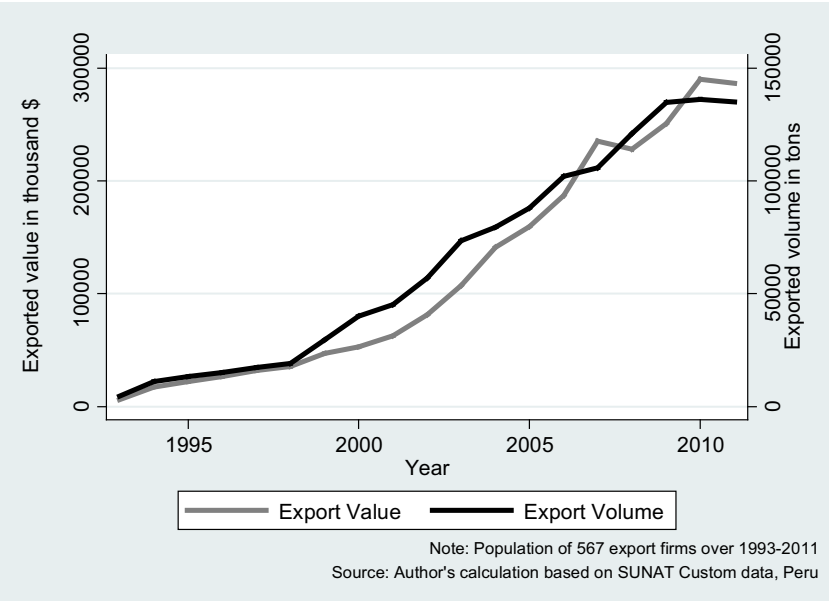

c) Export volume and value - by certification

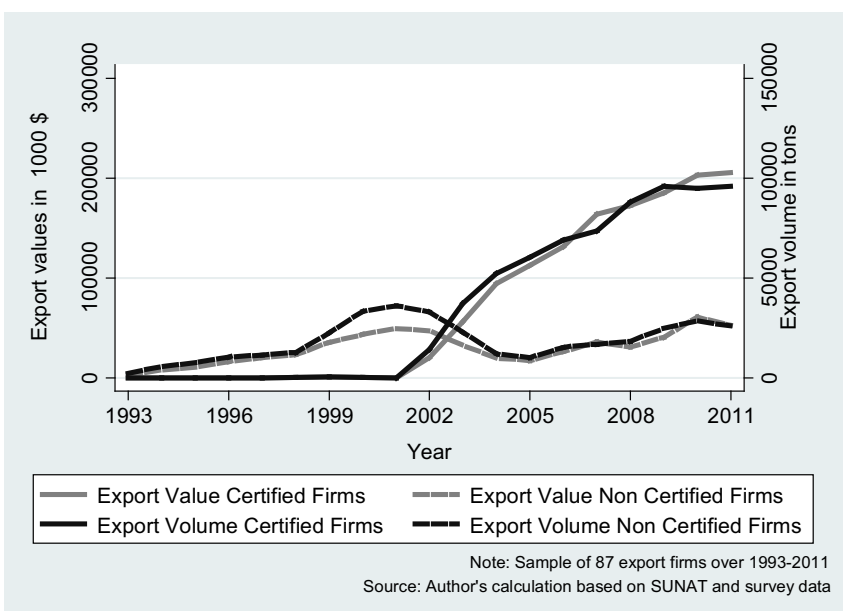

\section{b) Total number of export firms}

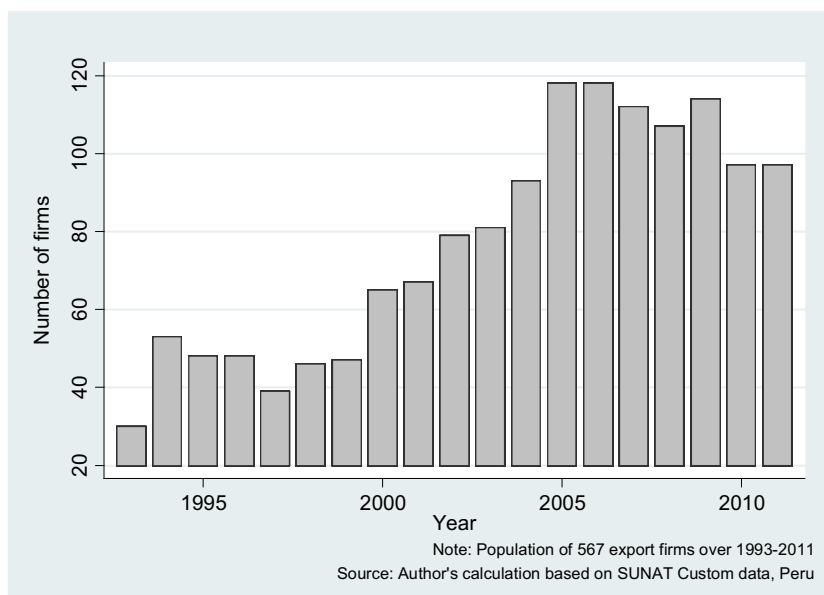

Figure 1. Evolution of fresh asparagus exports and export firms, 1993-2011.

at around 100 firms per year since 2006. Given a total number of 567 firms that ever exported fresh asparagus since 1993, these figures point to an absence of consolidation and a large transition in and out of exporting. The overall parallel pattern of export volumes and values in Figure 1a indicates that export prices remained relatively stable over the entire period.

Table 1 describes the average export performance at the firm level for 2001 and 2011. Out of all firms that ever exported fresh asparagus, 25\% were actively exporting in 2001 and $18 \%$ were actively exporting in 2011 . These figures confirm the large export entry and exit transitions. The average export volume of actively exporting firms doubled over the past decade, from 673 ton in 2001 to 1,405 ton in 2011, and the average export value tripled, from 937 thousand USD to almost 3 million USD (Table 1). When using unconditional export performance indicators, i.e. when including firms that are not actively exporting in specific years, the total export volumes and values per firm are lower, but still increase considerably over time. This indicates that Peruvian asparagus export firms are growing on average and in terms of total exported goods.

Table 1. Export performance of firms, 2001 versus 2011

\begin{tabular}{|c|c|c|c|c|c|c|}
\hline \multirow[t]{2}{*}{ Variables } & \multicolumn{3}{|c|}{2001} & \multicolumn{3}{|c|}{2011} \\
\hline & Mean & Std. Dev. & $N$ & Mean & Std. Dev. & $N$ \\
\hline Propensity to export (dummy) & 0.25 & 0.43 & 269 & 0.18 & 0.39 & 525 \\
\hline Export volume (in ton) & 167.8 & 659.07 & 269 & 257.03 & $1,215.25$ & 525 \\
\hline Export volume (in ton) — conditional on exporting & 673.72 & $1,190.71$ & 67 & $1,405.63$ & $2,552.32$ & 96 \\
\hline Export value (in th. \$) & 233.49 & 911.08 & 269 & 545.78 & $2,572.01$ & 525 \\
\hline Export value (in th. \$) - conditional on exporting & 937.45 & $1,643.36$ & 67 & $2,984.73$ & $5,397.42$ & 96 \\
\hline
\end{tabular}

Source: Own elaboration from SUNAT Data. 
Standard deviations of export volumes and values are large, indicating a large variability in firms' exports.

\section{(c) Certification to private standards}

Figure 1 also describes, for our sample, the evolution of export volumes and values for certified and non-certified firms (Figure 1c) and the evolution of the number of certified and non-certified firms (Figure 1d). The certified export volume and value increased rapidly from 2000 onward. Almost no produce was certified until the year 2000 but by 2003 the export volume of certified firms had already exceeded that of non-certified firms. The volume of non-certified asparagus decreased sharply during 2000-05, but increased slightly again after 2005. Similarly, the spread of certification among firms was most rapid in the early 2000s. By 2006, the number of certified firms surpassed the number of non-certified firms and remained stable from 2007-08 onward. At the individual firm level, this trend translates into an increased likelihood of certification; overall the share of certified companies increased from $7.1 \%$ in 2001 to $37.8 \%$ in 2011 (Table 2).

The rapid spread of certificates in the sector is related to the increased demand for compliance with stringent quality and safety standards by retailers in importing countries at the turn of the decade (Diaz, 2007). But also national initiatives have played a role in the spread of private standards. In 1998, the Asparagus National Technical Committee of Standardization (ANTCS) was established in order to develop national standards that would strengthen the food quality and safety capacity and to respond effectively to the requirements of importers and of national regulatory authorities of importing countries. ${ }^{4}$ These national initiatives provided a quality and performance baseline for the entire industry that allowed many firms to generate the skills and experience needed to become certified under various stringent international standards (Diaz, 2007).

The existing literature on standards (e.g., Henson \& Humphrey, 2010) classifies private standards according to the vertical scope or the extension along the value chain and subdivides them into pre-farm gate or production standards and post-farm gate or processing standards. The former regulate how farmers grow the crop and the latter oversee the transformation of the product. Both types of standards are important in the asparagus sector in Peru and experienced a rapid growth during the years 2000s. While in 2001, out of all companies in our sample, none was certified to a production standard and only $7 \%$ were certified to a processing standard, by 2011, respectively one third and one fourth of all companies are certified to at least one production or processing standard. ${ }^{5}$ As we can observe from Table 2, GlobalGAP is adopted by $34 \%$ of the sampled companies and is the most important private production standard in the sector. It was specifically developed to raise standards in the production of fresh fruit and vegetables and ensures a level playing field in terms of food safety and quality. The most important processing standards are HACCP and BRC, which are adopted by respectively $14 \%$ and $15 \%$ of all firms. HACCP and BRC are risk management systems, that apply primarily to the manufacturing of food packaging and filling operations. They both identify, evaluate, and control hazards related to food safety, but BRC has higher requirements concerning the adoption of a documented quality management system. Other production standards - similar to GlobalGAP — include SQF2000, Tesco Leaf and GAP, and other processing standards - similar to HACCP or BRC - are GMP, IFS, and SQF1000; these are less important in the studied sector and adopted by less than $10 \%$ of the companies.

Private certification in the Peruvian asparagus export sector is not perceived as a main market access issue, nor as an important market strategy for differentiation. In an open question included in the company survey carried out between July and September 2011, firms were asked to report the reasons for which they got certified to individual standards. Forty percent of all companies perceive certification to production standards as being an overall requirement from the market, but only $3 \%$ of all firms believe that production certification is a pre-condition for exporting at all. Processing standards are perceived to be more buyer-driven, as $60 \%$ of all companies declare that the standards are requested by specific importers and around $13 \%$ of the firms feel that they are indispensable for exporting. Another $20 \%$ and $15 \%$ of all firms declare that they respectively adopted production and processing

Table 2. Certification to private food standards, 2001 versus 2011

\begin{tabular}{|c|c|c|c|}
\hline \multirow[t]{2}{*}{ Certification variables ( $=1$ if certified) } & \multirow[t]{2}{*}{ Full specification } & \multicolumn{2}{|c|}{ Percentage of firms certified } \\
\hline & & $2001(N=26)$ & $2011(N=56)$ \\
\hline Certification & General certification variable & 7.1 & 37.8 \\
\hline Production standards & & 0 & 34.6 \\
\hline GlobalGAP & Global Good Agricultural Practice & 0 & 34.6 \\
\hline SQF2000 & Safe Quality Food Institute 2000 & 0 & 7.7 \\
\hline TESCO & Tesco Nurture (supermarket standard) & 0 & 6.4 \\
\hline LEAF & Linking Environment and Farming & 0 & 4.3 \\
\hline GAP & Good Agricultural Practice & 0 & 2.1 \\
\hline Processing standards & & 7.1 & 25 \\
\hline НАCCР & Hazard Analysis and Critical Control Point & 3.6 & 14.1 \\
\hline $\mathrm{BRC}$ & British Retail Consortium & 0 & 15.4 \\
\hline GMP & Good Manufacturing Practices & 3.6 & 7.5 \\
\hline IFS & International Food Standard & 0 & 2.4 \\
\hline SQF1000 & Safe Quality Food Institute 1000 & 0 & 1.1 \\
\hline \multicolumn{4}{|l|}{ Other standards } \\
\hline BASC & Business Alliance for Secure Commerce & 0 & 15.2 \\
\hline
\end{tabular}

Data from survey on stratified random sample; all sample means are weighted for the population average to control for the oversampling of consolidated and intermediate companies. 
standards without a direct external demand, but with the objective to innovate their internal company structures and of adding value to their company. In general, standards are thus adopted to follow an overall market trend, to respond to specific importers' demands and hence to eventually maintain companies' positions as reliable suppliers of asparagus to international markets. Due to a partial overlap of the types of certification schemes, companies are likely to get certified to different standards to respond to different market demands and without incurring very high additional costs.

\section{(d) Export firm characteristics}

Table 3 reports summary statistics on export performance and observable firm characteristics and compares certified and non-certified companies in 2011. Out of the 96 companies that were exporting fresh asparagus in 2011, 56 were included in our survey, of which 34 companies are certified to at least one private standard, while 22 do not adhere to any certification scheme. Firm characteristics and, in particular, firms' export performance differ substantially by certification. The 2011 export volumes and values of certified firms are significantly and on average almost three times higher than those of non-certified firms. Yet, already in $2003^{6}$ and 2006 before becoming certified, these companies had significantly larger exports. This indicates that certified firms perform better in the export market but that they already did so before being certified. The export volumes of currently certified firms grew significantly faster during the past decade than the exports of non-certified firms, with a yearly average relative growth of around $23 \%$ compared to around $6 \%$ for non-certified firms. Yet, differences are less pronounced for the relative growth of export values and differences are not statistically significant. Certified firms grew faster than non-certified firms in terms of the quantity exported, but not necessarily in terms of export value.

Certified and non-certified firms differ substantially in terms of observable characteristics. Out of all firms, 53\% own agricultural land and 49\% own a processing plant, but certified firms are more likely to own both agricultural land $(96 \%)$ and a processing plant $(85 \%)$ than non-certified firms $(32 \%$ and $28 \%$ respectively). The average landholdings are substantially larger for certified firms (52.86 ha) than for non-certified firms (3.6 ha). On average in 2011, asparagus export firms

Table 3. Export performance and firm characteristics for certified and non-certified firms that are actively exporting in 2011

\begin{tabular}{|c|c|c|c|c|c|c|c|c|}
\hline \multirow[t]{2}{*}{ Variables } & \multicolumn{3}{|c|}{ All firms } & \multicolumn{2}{|c|}{$\begin{array}{l}\text { Certified firms } \\
\quad(\mathrm{N}=34)\end{array}$} & \multicolumn{2}{|c|}{$\begin{array}{l}\text { Non certified firms } \\
\quad(N=22)\end{array}$} & \multirow[t]{2}{*}{ Comparison of means } \\
\hline & Mean & Std. Dev. & $\mathrm{N}$ & Mean & Std. Dev. & Mean & Std. Dev. & \\
\hline \multicolumn{9}{|l|}{ Firm export performance } \\
\hline \multicolumn{9}{|l|}{ Export volume } \\
\hline $2001\left(^{\wedge}\right)$-ton & 565.7 & $1,481.4$ & 96 & $1,387.0$ & $2,345.3$ & 191.2 & 677.7 & $*$ \\
\hline $2006(\wedge \wedge)$-ton & 910.6 & $1,777.8$ & 96 & $1,663.4$ & $4,327.1$ & 46.5 & 227.8 & $*$ \\
\hline 2011 -ton & $1,405.6$ & $2,552.3$ & 96 & $2,664.2$ & $4,032.3$ & 828.1 & $1,221.6$ & $* *$ \\
\hline$\%$ Growth 2001-11 & 9.2 & 214.2 & 521 & 22.9 & 355.26 & 6.1 & 21.3 & $*$ \\
\hline \multicolumn{9}{|l|}{ Export value } \\
\hline $2003(\wedge)$-in th. $\$$ & 835.7 & $2,223.3$ & 96 & $3,450.9$ & 3,313 & 1,276 & $1,205.0$ & $*$ \\
\hline $2006(\wedge \wedge)$-in th. $\$$ & $1,688.0$ & $3,745.3$ & 96 & $4,749.8$ & $5,718.4$ & $1,531.5$ & $1,705.2$ & $*$ \\
\hline 2011 -in th. $\$$ & $2,984.7$ & $5,397.4$ & 96 & $5,721.9$ & 8,408 & 1,672 & $2,507.3$ & $* *$ \\
\hline$\%$ Growth 2001-11 & 5 & 85.6 & 521 & 8.9 & 135.3 & 3.4 & 17.8 & \\
\hline \multicolumn{9}{|l|}{ Firm characteristics } \\
\hline Asparagus land (dummy) & 0.53 & 0.50 & 50 & 0.96 & 0.25 & 0.32 & 0.38 & $\begin{array}{c}* * \\
* * *\end{array}$ \\
\hline Asparagus land $(\mathrm{Ha})$ & 20.24 & 45.31 & 50 & 52.86 & 86.33 & 3.63 & 6.57 & $\begin{array}{c}* * * \\
* *\end{array}$ \\
\hline Processing plant & 0.49 & 0.50 & 57 & 0.85 & 0.46 & 0.28 & 0.36 & $* *$ \\
\hline Years exist & 8.02 & 6.37 & 96 & 13.11 & 6.06 & 4.99 & 3.05 & $* *$ \\
\hline years exporting & 6.58 & 5.65 & 96 & 10.52 & 6.47 & 3.63 & 2.76 & $*$ \\
\hline Pioneer $^{\mathrm{b}}$ & 0.24 & 0.43 & 62 & 0.59 & 0.63 & 0.05 & 0.18 & $*$ \\
\hline Foreign capital & 0.40 & 0.49 & 57 & 0.44 & 0.64 & 0.38 & 0.39 & \\
\hline Green asparagus & 94.46 & 20.49 & 59 & 86.31 & 39.72 & 99.04 & 5.22 & \\
\hline Administrative staff change & 0.08 & 0.28 & 96 & 0.03 & 0.21 & 0.12 & 0.26 & \\
\hline Organizational change & 0.03 & 0.18 & 56 & 0.03 & 0.21 & 0.03 & 0.15 & \\
\hline Double tax ID & 0.02 & 0.14 & 96 & 0.03 & 0.21 & 0.00 & 0.00 & \\
\hline Taxpayer "Good" & 0.03 & 0.18 & 96 & 0.06 & 0.30 & 0.12 & 0.26 & \\
\hline Number of production quarters ${ }^{\mathrm{b}}$ & 1.49 & 2.56 & 96 & 2.88 & 4.26 & 0.30 & 0.50 & $* * *$ \\
\hline Administrative quarters $\mathrm{s}^{\mathrm{b}}$ & 0.21 & 0.63 & 96 & 0.49 & 1.20 & 0.00 & 0.00 & $* * *$ \\
\hline Non-agricultural capital $^{\mathrm{b}}$ & 0.23 & 0.43 & 96 & 0.33 & 0.60 & 0.18 & 0.31 & $* *$ \\
\hline Ancash $^{\mathrm{b}}$ & 0.02 & 0.14 & 56 & 0.06 & 0.30 & 0.00 & 0.00 & \\
\hline $\mathrm{Ica}^{\mathrm{b}}$ & 0.59 & 0.50 & 56 & 0.64 & 0.61 & 0.56 & 0.40 & \\
\hline La Libertad $^{\mathrm{b}}$ & 0.30 & 0.46 & 56 & 0.25 & 0.55 & 0.33 & 0.38 & \\
\hline Lima $^{b}$ & 0.08 & 0.27 & 58 & 0.03 & 0.21 & 0.12 & 0.26 & \\
\hline
\end{tabular}

All sample means are weighted for the population average to control for the oversampling of consolidated and intermediate companies; $\left({ }^{\wedge}\right)$ Number of companies that are exporting in 2011 and in 2001: $N=25$, of which 'certified comp'.: $N=21$, 'Non certified comp'.: $N=4 ;(\wedge \wedge)$ Number of companies that were exporting in 2011 and in 2006: $N=37$, of which 'certified comp': $N=28$, 'Non certified comp'.: $N=9$.

${ }^{\mathrm{a}} t$-Tests $*, * *$ and $* * *$ denote $10 \%, 5 \%$ and $1 \%$ significance level, respectively.

${ }^{\mathrm{b}}$ Time constant variables. 
existed for more than 8 years and had almost 7 years of export experience. Certified firms are significantly older (13 years) and have significantly more years of export experience (10 years) than non-certified firms ( $\sim 5$ and 4 years), which could indicate that there is less entry and exit among certified firms. Indeed, $59 \%$ of the currently certified firms are pioneers who were already in the market before 2003 while this is barely $5 \%$ for non-certified firms. Out of all firms, $40 \%$ rely on foreign capital; this is slightly but not significantly larger among certified firms $(44 \%)$ than among non-certified firms $(38 \%)$. The large majority of all firms grows green asparagus (94\% of all firms) and the cultivation of white asparagus is concentrated in the hands of few large, mostly certified, export companies in northern Peru. During their lifespan companies experience administrative and organizational changes, but these are relatively rare (respectively around $8 \%$ and $3 \%$ of all companies) and are not more frequent in certified or non-certified companies. Exports under two different tax identifiers, the classification as being a good taxpayer and the location of certified and non-certified firms differs slightly but not significantly. Significant differences are observed in the company's number of production quarters, administrative offices, and origin of the starting capital, which are all variables related to the size of a company.

\section{ECONOMETRIC APPROACH}

To assess whether the observed differences in export performance between certified and non-certified firms are due to the causal impact of certification we estimate the following regression model:

Export $_{i t}=\beta_{0}+\beta_{1} C_{i t}+\beta_{2} X_{i t}+D_{t}+v_{i t}$

To estimate effects at the intensive and extensive margin of trade, the dependent variable Export $t_{i t}$ is specified in five different ways: 1, as a dummy variable equaling one if firm $i$ is exporting in year $t ; 2$ and 3 , as the logarithm of the export volume (2) or the export value (3) of firm $i$ in year $t$, being positive when the firm exports or zero when the firm does not export in year $t ; 4$ and 5, as the logarithm of the export volume (4) or the export value (5) of firm $i$ in year $t$, conditional on exporting in that year.

The key variable of interest in the model is the variable for certification of firm $i$ in year $t, C_{i t}$. This is a dummy variable equaling one if firm $i$ is certified to any type of standards, to a production or processing standard, or to a particular individual standard (including GlobalGAP, HACCP, BRC and BASC - to which at least $15 \%$ of all companies are certified in 2011). When looking at production, processing, and individual standards, we reduce our sample of firms according to the applicability of the type of certification. Only firms cultivating land are kept when analyzing the effect of production certifications, while only firms that are (also) processing their own products are included in the analysis on processing certifications. The BASC certification is relevant for all types of firms, cultivating and/or processing the export product and the full sample is thus used for the analysis.

The vector $X_{i t}$ is a large set of observable firm characteristics related to the type and size of the firm, experience, access to foreign capital, tax pay regime, management changes, and location-these variables ${ }^{7}$ are described in Table 3. Year dummies $D_{t}$ are included to control for common macroeconomic effects and $v_{i t}$ is the error term.

The main difficulty in estimating Eqn. (1) and identifying the causal impact of certification to private standards $C_{i t}$ on firms' export performance Export $t_{i t}$ is that the voluntary certification decision of firms is potentially endogenous. The endogeneity could be due to 1 , potential reverse causality, i.e., certification decisions might be determined by current export performance; 2 , certification being predetermined, i.e., certification might depend on past export performance, which also affects current exports; 3, time-constant unobserved heterogeneity, i.e., timeconstant unobserved factors being contemporaneously correlated with exports and certification; or 4, time-varying unobserved heterogeneity, i.e., lagged dynamic unobserved factors affecting certification and having a persistent effect on export performance. The recent empirical trade literature has shown that export persistence and unobserved firm heterogeneity are important in explaining export performance. Failing to control for past export behavior and unobservable characteristics would likely lead to an overestimation of the impact of certification on export performance. We use several estimation techniques to control for dynamic and unobserved effects. ${ }^{8}$

First, we ignore firm-specific unobserved effects and the dynamic export pattern and estimate Eqn. (1) using OLS. ${ }^{9}$ We expect that, due to past exports and unobserved factors being positively (negatively) correlated with certification and with current exports, OLS is leading to an upward bias in estimating the effect of certification on export performance.

Second, we account for export persistence over time by including a one-year lag of the respective dependent variable Export $_{i, t-1}$ in the model, as specified in Eqn. (2). Since past export performance is likely positively correlated with the current certification decision and with current export performance, we expect the bias on the certification variable to decrease.

Export $_{i t}=\beta_{0}+\beta_{1} C_{i t}+\beta_{2} X_{i t}+\beta_{3}$ Export $_{i, t-1}+D_{t}+v_{i t}$

Third, we explicitly consider the role of unobserved firm heterogeneity and re-specify the equation by decomposing the error term $v_{i t}$ in a time-constant $\varepsilon_{i}$ and a time-varying component $u_{i t}$. Eqn. (3) specifies a fixed effects model in which time-constant unobserved heterogeneity $\varepsilon_{i}$ can be eliminated. We estimate the model using the standard within (fixed effects) estimator.

Export $_{i t}=\beta_{0}+\beta_{1} C_{i t}+\beta_{2} X_{i t}+\beta_{3}$ Export $_{i, t-1}+D_{t}+u_{i t}+\varepsilon_{i}$

With this strategy we can control for time-constant unobserved heterogeneity but a problem remains (Nickell, 1981). Lagged export performance Export $_{i, t-1}$ is not strictly exogenous, which could lead to a downward bias in the estimated coefficient $\beta_{3}$ (Bond, 2002). Also certification $C_{i t}$ is likely not strictly exogenous and if a positive (negative) shock to past export performance positively (negatively) affects the likelihood of certification, the standard fixed effects estimator would lead to a downward (upward) bias in the estimated certification coefficient $\beta_{1}$ (Bond, 2002). Therefore, we expect the fixed effects estimator to result in a downward bias of the estimated effect of certification on export performance.

Fourth, to deal with this remaining problem we estimate the model using the System General Method of Moments (System GMM) approach (Arellano \& Bond, 1991). This method combines first difference transformation to eliminate time-constant unobserved heterogeneity $\varepsilon_{i}$ with an instrumental variable estimation to further reduce remaining endogeneity bias. Lagged levels of the explanatory variables and further lags of the dependent variable are used as instruments in the firstdifference equation while lagged first-differences of these variables ${ }^{10}$ are used as instruments in the levels equations, and the moment conditions of the first difference and the levels equations are combined in the System GMM 
(Arellano \& Bond, 1991; Arellano \& Bover, 1995; Blundell \& Bond, 1998; Bond, 2002). For the choice of the instruments it is important to ascertain whether the explanatory variables are strictly exogenous (independent), predetermined (depending on past exports), or simultaneously endogenous (depending on current exports). We treat the time dummies $D_{t}$ as exogenous, certification $C_{i t}$ as endogeneous ${ }^{11}$ and all but one firm characteristics $X_{i t}$ as predetermined. The variable 'asparagus land' is also treated as endogenous because land can be converted to other crops or rented out rather quickly in response to export shocks, while adaptation of other firm characteristics to changes in the export performance is not immediate. Predetermined variables are instrumented with three lags in the difference equation and with their difference lagged once in the levels equation. For the endogenous variables the number of instruments is reduced by one, as only lags two and up are valid. All instruments are collapsed in order to limit the instrument count (Roodman, 2009). The validity of all instruments and the additional moment conditions from the equation in levels are tested respectively with the Hansen test of over-identification restrictions and the Hansen difference test. We believe that the System GMM estimator gives the most correct estimates with the smallest bias.

Fifth, we use the same System GMM estimator as above but extend the lagged instruments by one level in the difference equation. This comes down to instrumenting all first differenced predetermined variables with their levels from one to four inclusive and the endogenous variables from two to four inclusive; in the levels equation the number of instruments does not change. To the extent that this specification of the system GMM estimator introduces more information, it should improve efficiency, and at the same time test the robustness of the results to an alternative set of instruments (Roodman, 2007; Roodman, 2009).

With the GMM strategy we are able to eliminate endogeneity problems arising from reverse causality, predetermined dependence on past performance and time-constant unobserved heterogeneities. The problem of endogeneity arising from lagged omitted variables with persistent impacts on export performance is not fully addressed, but we deem remaining bias to be limited as lagged dependent variables, dummy variables for management and organizational changes, and a wide set of other observable variables likely capture a large part of the time-varying characteristics. ${ }^{12}$ Moreover, the GMM method shows that results are robust to the extension or reduction of lagged right hand side instruments; results thus do not depend on a specific lagged certification being correlated with a year-specific omitted variable. A final problem arises when considering the conditional export volumes and values as dependent variables. If unobservable firm characteristics affect both firms' decision to export and the quantity exported, there is an additional selection bias problem. This would lead to additional bias especially in the OLS estimation but is also (partially) controlled for in the fixed effects and System GMM estimation.

\section{RESULTS AND DISCUSSION}

\section{(a) Impact of certification on export performance}

Table 4 reports regression results for the main variable of interest, certification to private standards. Results are reported

Table 4. Certification to any private standard and firms' export performance

\begin{tabular}{|c|c|c|c|c|c|}
\hline \multicolumn{6}{|c|}{ Coefficients for certification ( $=1$ if certified $;=0$ not certified $)$} \\
\hline \multirow[t]{2}{*}{ Dep Var } & \multicolumn{5}{|c|}{ Model } \\
\hline & $\begin{array}{l}\text { OLS } \\
(1)\end{array}$ & $\begin{array}{l}\text { OLS } \\
(2)\end{array}$ & $\begin{array}{l}\text { FE } \\
\text { (3) }\end{array}$ & $\begin{array}{c}\text { Sys-GMM } \\
\text { (4) }\end{array}$ & $\begin{array}{c}\text { Sys-GMM } \\
\text { (5) }\end{array}$ \\
\hline Export dummy & $\begin{array}{c}0.209^{* * *} \\
(0.071) \\
N=785\end{array}$ & $\begin{array}{c}0.101^{* *} \\
(0.044) \\
N=713\end{array}$ & $\begin{array}{c}0.113 \\
(0.071) \\
N=713\end{array}$ & $\begin{array}{c}0.089 \\
(0.079) \\
N=713\end{array}$ & $\begin{array}{c}0.093 \\
(0.073) \\
N=713\end{array}$ \\
\hline Export values (th \$) & $\begin{array}{c}3.046^{* * *} \\
(1.072) \\
N=785\end{array}$ & $\begin{array}{c}1.030^{*} \\
(0.534) \\
N=713\end{array}$ & $\begin{array}{c}0.785 \\
(0.757) \\
N=713\end{array}$ & $\begin{array}{c}0.735 \\
(0.793) \\
N=713\end{array}$ & $\begin{array}{c}0.694 \\
(0.727) \\
N=713\end{array}$ \\
\hline Export volumes (ton), conditional on exporting & $\begin{array}{c}0.407 \\
(0.475) \\
N=499\end{array}$ & $\begin{array}{c}0.109 \\
(0.382) \\
N=468\end{array}$ & $\begin{array}{c}-0.701 \\
(0.428) \\
N=468\end{array}$ & $\begin{array}{c}0.404 \\
(0.788) \\
N=468\end{array}$ & $\begin{array}{c}0.451 \\
(0.752) \\
N=468\end{array}$ \\
\hline Time trend & No & Yes & Yes & Yes & Yes \\
\hline Year and location dummies & Yes & Yes & Yes & Yes & Yes \\
\hline Covariates & Yes & Yes & Yes & Yes & Yes \\
\hline
\end{tabular}

Company cluster robust standard errors in parenthesis for the OLS and FE estimations. Robust finite samples corrected standard errors (Windmeijer,

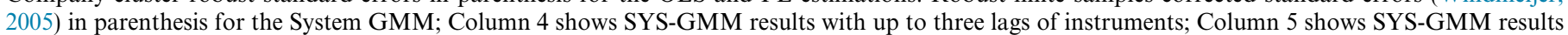

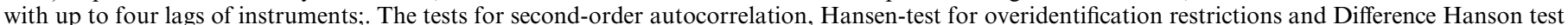
are not reported in columns 4 and 5 but all accepted at above the $10 \%$ significance level.

${ }^{*} p<0.1$.

${ }_{* * *}^{* *}<0.05$.

$p<0.01$. 
for the different export performance indicators - an export dummy variable and conditional and unconditional export volumes and values - and for different estimation methodsOLS without lagged exports (Model 1), OLS with lagged exports (Model 2), fixed effects (Model 3), system GMM with up to three period lags as instruments (Model 4), and system GMM with up to four period lags as instruments (Model 5). In all regressions we control for observable covariates, time and location dummies.

Our main result is that, when controlling for export persistence, unobserved heterogeneity and reverse causality, we do not find any evidence that certification has a significant impact on companies' export performance, neither at the extensive margin nor at the intensive margin, and neither on export volumes nor on export values. We find a significant positive effect of certification on the export dummy and the unconditional export volumes and values when using an OLS estimation without controlling for export persistence (Model 1). The effect reduces sharply but remains significant when time trends are controlled for (Model 2) and becomes completely insignificant in the fixed effects (Model 3) and System GMM (Models 4 and 5 ) estimation. The estimated effects from the OLS regression without time trends are two to four times larger than the estimated effects in the other Models. This is in line with our expectations that OLS without lagged dependent variable overestimates the effect because of a positive correlation between past export performance and certification, because of unobserved firm characteristics being contemporaneously correlated with certification and export performance, and because of reverse causality. We believe the System GMM estimations are the most correct ones with the smallest bias in the estimated coefficients.

When estimating the impact of certification on export volumes and values conditional on exporting in year $t$, we find no significant effect at all in any of the models. The estimated coefficients for the certification variable are substantially lower when considering conditional export volumes and values than when considering unconditional export volumes and values. This is most apparent in the OLS models where we do find a significant effect on the probability of exporting and on unconditional export volumes and values but not on conditional export volumes and values. This implies that certification is more correlated with the likelihood of exporting, i.e. the extensive margin than with the intensity of exporting, i.e. the intensive margin. Also the reduced sample size - stemming from the fact that companies do not export in all years - may result in larger standard errors of the estimates and a lack of significant effects in the OLS models.

In order to account for eventual heterogeneous effects, in Table 5 we split up the analysis and run the models separately for production standards, processing standards and the most common individual standards. Again different export performance indicators are used and observable covariates, time, and location dummies are controlled for. The analysis is now restricted to different subgroups of our dataset, according to the applicability of the type of certification. In columns 1 and 2 of Table 5, we only look at firms cultivating land and for which production certifications are applicable, while in columns 3-5 we only look at firms that are (also) processing their own products and for which processing certifications are

Table 5. Certification to specific private standards and export performance

\begin{tabular}{|c|c|c|c|c|c|c|}
\hline \multicolumn{7}{|c|}{ Independent variable - main certification schemes $(=1$ if certified; $=0$ not certified $)$} \\
\hline \multirow[t]{2}{*}{ Dep Var } & \multicolumn{6}{|c|}{ Certification } \\
\hline & \multicolumn{2}{|c|}{ Production standards } & \multicolumn{3}{|c|}{ Processing standards } & $\begin{array}{c}\text { Other type of standard } \\
\text { BASC } \\
(6)\end{array}$ \\
\hline Export dummy & $\begin{array}{c}0.064 \\
(0.065) \\
N=326\end{array}$ & $\begin{array}{c}0.061 \\
(0.065) \\
N=325\end{array}$ & $\begin{array}{c}0.038 \\
(0.049) \\
N=388\end{array}$ & $\begin{array}{c}0.007 \\
(0.051) \\
N=388\end{array}$ & $\begin{array}{c}0.084 \\
(0.078) \\
N=388\end{array}$ & $\begin{array}{c}-0.002 \\
(0.084) \\
N=696\end{array}$ \\
\hline Export volumes (ton) & $\begin{array}{c}0.39 \\
(0.721) \\
N=326\end{array}$ & $\begin{array}{c}0.35 \\
(0.720) \\
N=325\end{array}$ & $\begin{array}{c}0.097 \\
(0.587) \\
N=388\end{array}$ & $\begin{array}{c}0.578 \\
(0.570) \\
N=388\end{array}$ & $\begin{array}{c}0.943 \\
(0.804) \\
N=388\end{array}$ & $\begin{array}{c}-0.358 \\
(0.891) \\
N=696\end{array}$ \\
\hline Export values (th $\$$ ) & $\begin{array}{c}0.381 \\
(0.766) \\
N=326\end{array}$ & $\begin{array}{c}0.338 \\
(0.763) \\
N=325\end{array}$ & $\begin{array}{c}0.155 \\
(0.620) \\
N=388\end{array}$ & $\begin{array}{c}0.65 \\
(0.605) \\
N=388\end{array}$ & $\begin{array}{c}1.014 \\
(0.855) \\
N=388\end{array}$ & $\begin{array}{c}-0.338 \\
(0.915) \\
N=696\end{array}$ \\
\hline $\begin{array}{l}\text { Export values (th } \$ \text { ), conditional } \\
\text { on exporting }\end{array}$ & $\begin{array}{c}0.35 \\
(0.534) \\
N=275\end{array}$ & $\begin{array}{c}0.279 \\
(0.518) \\
N=275\end{array}$ & $\begin{array}{c}-0.842 \\
(0.649) \\
N=298\end{array}$ & $\begin{array}{c}0.384 \\
(1.223) \\
N=298\end{array}$ & $\begin{array}{c}-0.806 \\
(1.474) \\
N=298\end{array}$ & $\begin{array}{c}-1.068 \\
(0.980) \\
N=457\end{array}$ \\
\hline $\begin{array}{l}\text { Year dummies } \\
\text { Covariates }\end{array}$ & $\begin{array}{l}\text { Yes } \\
\text { Yes }\end{array}$ & $\begin{array}{l}\text { Yes } \\
\text { Yes }\end{array}$ & $\begin{array}{l}\text { Yes } \\
\text { Yes }\end{array}$ & $\begin{array}{l}\text { Yes } \\
\text { Yes }\end{array}$ & $\begin{array}{l}\text { Yes } \\
\text { Yes }\end{array}$ & $\begin{array}{l}\text { Yes } \\
\text { Yes }\end{array}$ \\
\hline Sample & If cultivated la & $\mathrm{d} d>0$ & If firm owns a & processing 1 & & Full sample \\
\hline
\end{tabular}

Columns show SYS-GMM results with up to three lags of instruments. Robust finite samples corrected standard errors (Windmeijer, 2005) in parenthesis for the System GMM; ${ }^{* * *} p<0.01,{ }^{* *} p<0.05,{ }^{*} p<0.1$. The tests for second-order autocorrelation, Hansen-test for overidentification restrictions and Difference Hanson test are not reported but all accepted at above the $10 \%$ significance level. 
relevant. The BASC certification is relevant for all types of firms and the full sample is used in column 6. Only results from the System GMM Model are reported, as this gives the most credible estimates with the smallest bias. The outcomes from Table 5 show that different types of private certification schemes, referring to either production or processing standards, have a similar non-significant effect on firms' export performance. The results corroborate the findings above that, when controlling for export persistence, unobserved effects and reverse causality, we do not find evidence that individual private standards improve firms' export performance, neither at the extensive margin nor at the intensive margin. Results from regressions on individual standards show smaller coefficients and standard errors, as compared to the more general regressions in Table 4, which supports our conclusion that there is no evidence of an effect of any type of certification on export performance.

Our result that certification to private standards does not improve firms' export performance challenges the "standardsas-catalyst" view and previous firm-level evidence on exportenhancing effects of private standards, provided by Henson et al. (2011) and Volpe-Martincus et al. (2010). Explanations for these diverging findings are likely to relate to the nature of the specific case that is studied and to differences in methodology. Peru already had a long tradition of asparagus exports before private standards started to become important in international markets at the start of the 2000s. This long history and the initiatives undertaken at the national level (see Section 3), might limit the cost of compliance with stringent standards as firms already have the skills and experience needed for such compliance. In this context, also the benefits of certification might be limited if standards do not substantially change production and management practices in the industry and certificates do not enforce anything companies had not already implemented before. Variations in destination market for specific food exports may likewise play a role in explaining differences in findings. In addition and in line with the theory of industrial clustering and cross-firm externalities (Cadot, Iacovone, Pierola, \& Rauch, 2013; Giuliani et al., 2005), positive performance spill-over effects from certified to non-certified companies might have played a role in the development of the entire asparagus export industry in the past decade.

We believe that methodological differences also largely contribute to explaining the contradicting findings between our study and previous firm-level studies We find large differences between OLS estimates and estimates from FE and system GMM methods, which indicates that failure to control for export persistence and for time-constant unobserved heterogeneity, as was the case in previous studies, might lead to an overestimation of the impact of private standards.

\section{(b) Full regression results}

We report the full regression results for the preferred System GMM estimation in Table 6. ${ }^{13}$ First, we find that the null hypotheses of no second-order autocorrelation of residuals, of the joint validity of all instruments (Hansen test) and of the joint validity of the additional instruments used in the System GMM estimation (Difference Hansen test) cannot be rejected at the $5 \%$ or $10 \%$ significance level. This confirms the validity of the instruments used.

Second, we find that other firm characteristics have an impact on export performance as well. Lagged exports have a significant and large positive effect on current exports, which is an indication of the expected export persistence. This effect is consistent for the different export performance indicators and the magnitude of the effect is similar to that reported by other authors (e.g., Bernard \& Jensen, 2004). Further, we find that ownership of a processing plant and of more agricultural land do not significantly affect firms' propensity to export but do have a significant positive - and for land a decreasingeffect on the export volume and value. This implies that larger and established processing and production firms perform better in the export market but are not necessarily more likely to be in the market in specific years. This might indicate that fixed investment costs affect firms' export performance, but cannot avoid entry and exit behavior. The age of a firm has a u-shaped effect and export experience an inverse u-shaped effect on export performance, with turning points around 13 and 9 years respectively. The negative and decreasing effect of age could be related to issues such as idleness or lower adaptability. Finally, having multiple tax identifiers and a status as good taxpayer positively affect firms' total export volume and value and the likelihood of exporting but not the conditional export volume and value. Facing a lower tax burden - either artificially because firms split up and pay taxes on two small, instead of one large firm or because they are classified as reliable entities by the national tax authority-has a positive effect on firms' exports at the extensive margin.

\section{CONCLUSION AND IMPLICATIONS}

In this paper we have analyzed the firm-level trade effects of certification to private standards in the fresh asparagus export sector in Peru. When controlling for export persistence, timeconstant unobserved heterogeneity and reverse causality, we do not find any evidence that certification to private standards in general and to specific individual private standards, has an effect on firms' export performance, neither at the extensive margin nor at the intensive margin, and neither on export volumes nor on export values. Our results indicate that exports are sticky and that unobserved firm characteristics (e.g., entrepreneurial ability, openness toward innovations, personal links with importers) play an essential role in determining both export performance and certification decisions. Our results imply that private standards do not enhance trade; which does not necessarily mean that they impede trade either.

These results are in line with the recent trade literature highlighting the importance of firm characteristics in understanding export performance, but are different from earlier empirical findings on the firm-level trade effect of private food standards. In comparison with previous cross-sectional studies, we believe that we have made methodological improvements that resulted in more correct estimates of the impact of private standards on firms' export performance. Our results show that controlling for export persistence, reverse causality and time-constant unobserved heterogeneity is important as it leads to very different findings on the impact of private standards. In addition, the trade effect of voluntary standards might be highly sector specific (Shepherd \& Wilson, 2013). Peru is a middle-income country that had a well-established asparagus export sector with established buyer-seller relations and relatively high safety and quality standards, even before private standards started to spread. Previous studies, particularly the paper by Henson et al. (2011) on the impact of GlobalGAP certification on horticultural exports from Africa, look at emerging export sectors in low-income countries. The study by Volpe-Martincus et al. (2010) looks at a middle-income country, but merges all types of industries, where the 
Table 6. Regressions on firms' export performance-results from System GMM

\begin{tabular}{|c|c|c|c|c|c|}
\hline \multirow[t]{2}{*}{ Ind Var } & \multicolumn{5}{|c|}{ Dep Var } \\
\hline & $\begin{array}{l}\text { Export } \\
\text { Dummy } \\
\text { (1) }\end{array}$ & $\begin{array}{l}\text { Export } \\
\text { Volume } \\
\text { (2) }\end{array}$ & $\begin{array}{l}\text { Export } \\
\text { Value } \\
\text { (3) }\end{array}$ & $\begin{array}{c}\text { Export } \\
\text { Volume, conditional } \\
\text { on exporting } \\
(4)\end{array}$ & $\begin{array}{l}\text { Export Value, } \\
\text { conditional on } \\
\text { exporting } \\
(5)\end{array}$ \\
\hline Certification dummy & $\begin{array}{c}0.093 \\
(0.073)\end{array}$ & $\begin{array}{c}0.688 \\
(0.692)\end{array}$ & $\begin{array}{c}0.694 \\
(0.727)\end{array}$ & $\begin{array}{c}0.451 \\
(0.752)\end{array}$ & $\begin{array}{c}0.41 \\
(0.780)\end{array}$ \\
\hline Export dummy $(t-1)$ & $\begin{array}{l}0.406^{* * *} \\
(0.077)\end{array}$ & & & & \\
\hline Export volumes $(t-1)$ & & $\begin{array}{c}0.576^{* * *} \\
(0.062)\end{array}$ & & $\begin{array}{c}0.075^{* * *} \\
(0.029)\end{array}$ & \\
\hline Export values $(t-1)$ & & & $\begin{array}{l}0.583^{* * *} \\
(0.062)\end{array}$ & & $\begin{array}{l}0.066^{* *} \\
(0.030)\end{array}$ \\
\hline Processing plant & $\begin{array}{c}0.126 \\
(0.077)\end{array}$ & $\begin{array}{c}2.298^{* * *} \\
(0.875)\end{array}$ & $\begin{array}{l}2.398^{* * *} \\
(0.899)\end{array}$ & $\begin{array}{l}0.795^{*} \\
(0.399)\end{array}$ & $\begin{array}{l}0.887^{*} \\
(0.486)\end{array}$ \\
\hline Asparagus land ${ }^{\mathrm{a}}$ & $\begin{array}{c}0.004 \\
(0.003)\end{array}$ & $\begin{array}{c}0.066^{* * *} \\
(0.026)\end{array}$ & $\begin{array}{l}0.067^{* *} \\
(0.027)\end{array}$ & $\begin{array}{c}0.052^{* * *} \\
(0.016)\end{array}$ & $\begin{array}{c}0.049^{* * *} \\
(0.017)\end{array}$ \\
\hline Asparagus land $2^{\mathrm{a}}$ & $\begin{array}{c}-0.000^{*} \\
0.000\end{array}$ & $\begin{array}{c}-0.000^{* *} \\
0.000\end{array}$ & $\begin{array}{c}-0.000^{* *} \\
0.000\end{array}$ & $\begin{array}{c}-0.000^{* * *} \\
0.000\end{array}$ & $\begin{array}{c}-0.000^{* *} \\
0.000\end{array}$ \\
\hline Years exist & $\begin{array}{c}-0.132^{* * *} \\
(0.026)\end{array}$ & $\begin{array}{c}-1.376^{* * *} \\
(0.269)\end{array}$ & $\begin{array}{c}-1.427^{* * *} \\
(0.281)\end{array}$ & $\begin{array}{c}-0.890^{* * *} \\
(0.262)\end{array}$ & $\begin{array}{c}-0.911^{* * *} \\
(0.263)\end{array}$ \\
\hline Years exist 2 & $\begin{array}{c}0.005^{* * *} \\
(0.001)\end{array}$ & $\begin{array}{c}0.053^{* * *} \\
(0.014)\end{array}$ & $\begin{array}{c}0.055^{* * *} \\
(0.015)\end{array}$ & $\begin{array}{c}0.033^{* * * *} \\
(0.012)\end{array}$ & $\begin{array}{c}0.035^{* * * *} \\
(0.012)\end{array}$ \\
\hline Years exporting & $\begin{array}{c}0.077^{* * *} \\
(0.022)\end{array}$ & $\begin{array}{c}0.596^{* * *} \\
(0.203)\end{array}$ & $\begin{array}{c}0.608^{* * *} \\
(0.213)\end{array}$ & $\begin{array}{c}0.730^{* * *} \\
(0.236)\end{array}$ & $\begin{array}{c}0.748^{* * *} \\
(0.245)\end{array}$ \\
\hline Years exporting2 & $\begin{array}{c}-0.004^{* * *} \\
(0.001)\end{array}$ & $\begin{array}{c}-0.031^{* * *} \\
(0.012)\end{array}$ & $\begin{array}{c}-0.032^{* * *} \\
(0.012)\end{array}$ & $\begin{array}{c}-0.029^{* * *} \\
(0.011)\end{array}$ & $\begin{array}{c}-0.031^{* * *} \\
(0.012)\end{array}$ \\
\hline Green asparagus $(\%)$ & $\begin{array}{l}-0.005 \\
(0.004)\end{array}$ & $\begin{array}{l}-0.015 \\
(0.034)\end{array}$ & $\begin{array}{c}-0.02 \\
(0.036)\end{array}$ & $\begin{array}{l}-0.015 \\
(0.021)\end{array}$ & $\begin{array}{l}-0.025 \\
(0.022)\end{array}$ \\
\hline Double tax ID & $\begin{array}{l}0.126^{* *} \\
(0.057)\end{array}$ & $\begin{array}{l}1.224^{* *} \\
(0.593)\end{array}$ & $\begin{array}{l}1.281^{* *} \\
(0.620)\end{array}$ & $\begin{array}{c}-0.02 \\
(0.281)\end{array}$ & $\begin{array}{l}-0.029 \\
(0.278)\end{array}$ \\
\hline Organizational Change & $\begin{array}{c}0.084 \\
(0.087)\end{array}$ & $\begin{array}{c}1.559 \\
(1.043)\end{array}$ & $\begin{array}{c}1.618 \\
(1.060)\end{array}$ & $\begin{array}{c}0.521 \\
(0.385)\end{array}$ & $\begin{array}{c}0.608 \\
(0.382)\end{array}$ \\
\hline Admin staff change & $\begin{array}{l}-0.016 \\
(0.058)\end{array}$ & $\begin{array}{c}0.26 \\
(0.714)\end{array}$ & $\begin{array}{c}0.244 \\
(0.759)\end{array}$ & $\begin{array}{c}0.055 \\
(0.244)\end{array}$ & $\begin{array}{c}0.054 \\
(0.241)\end{array}$ \\
\hline Foreign capital & $\begin{array}{c}0.109 \\
(0.192)\end{array}$ & $\begin{array}{c}1.047 \\
(1.694)\end{array}$ & $\begin{array}{c}1.141 \\
(1.801)\end{array}$ & $\begin{array}{c}0.038 \\
(1.038)\end{array}$ & $\begin{array}{c}0.05 \\
(1.018)\end{array}$ \\
\hline Taxpayer "good" & $\begin{array}{c}0.281^{* * *} \\
(0.108)\end{array}$ & $\begin{array}{l}2.700^{* *} \\
(1.150)\end{array}$ & $\begin{array}{l}2.889^{* *} \\
(1.238)\end{array}$ & $\begin{array}{c}0.59 \\
(0.669)\end{array}$ & $\begin{array}{c}0.756 \\
(0.631)\end{array}$ \\
\hline Constant & $\begin{array}{c}0.990^{* * *} \\
(0.361)\end{array}$ & $\begin{array}{c}6.387^{*} \\
(3.288)\end{array}$ & $\begin{array}{l}7.047^{* *} \\
(3.419)\end{array}$ & $\begin{array}{c}13.252^{* * * *} \\
(2.173)\end{array}$ & $\begin{array}{c}15.001^{* * *} \\
(2.235)\end{array}$ \\
\hline Year and location dummies & Yes & Yes & Yes & Yes & Yes \\
\hline$N$ & 713 & 713 & 713 & 468 & 468 \\
\hline Number of collapsed IV's & 76 & 76 & 76 & 76 & 76 \\
\hline Second-order autocorrelation & 0.095 & 0.17 & 0.217 & 0.158 & 0.149 \\
\hline Hansen test: overidentification restrictions ( $p$-value) & 0.32 & 0.425 & 0.394 & 0.567 & 0.652 \\
\hline Diff Hansen test ( $p$-value) & 0.785 & 0.604 & 0.633 & 0.524 & 0.459 \\
\hline
\end{tabular}

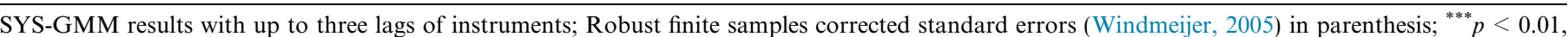
${ }^{* *} p<0.05,{ }^{*} p<0.1 ;{ }^{\text {a }}$ divided by 10 hectares.

establishment of specific national standards previous to the spread of the ISO standards they analyze is less clear. In such settings the signaling role of certification is possibly more important and private standards might be essential to convey reliable information to importers on the features of the, to them unknown, products and production processes. In the Peruvian asparagus industry, the signaling role of standards is less relevant because of already existing trading relations and lower information asymmetries. It might well be that in other contexts private standards have a more important impact. This could be the case in less established export sectors, such as in Africa where fresh horticultural exports developed more recently (Maertens, Minten, \& Swinnen, 2012), in less targeted export industries, where less importance is given to national safety and quality initiatives, or in low-income countries where implicit norms differ strongly from international standards.

Our analysis on the effect of certification to private standards on firms' export performance entails particular shortcomings. First, we only look at the direct effect of private standards on exports. Yet, spillover effects might be important as well and require a different approach to be addressed. As a market signaling tool, certification might not only affect the export performance of certified firms but also those of other non-certified firms. We find that there is no straightforward benefit for certified firms, but from our analysis we cannot say anything about the impact of certification on the entire industry sales through indirect effects. Again, the importance of such an 
indirect effect of private standards might also be sector specific and likely differs for emerging and well-established export sectors. Second, due to data limitations, we distinguished between effects at the intensive and extensive margin in a rather rough way. We only looked at whether certification changes firms' propensity to export but there might be diverging effects on exports to different markets as the adoption of private standards likely differs across destination markets. Also, private standards might lead to changes in destination markets. We believe that these issues are important to address in future research on the trade implications of private standards.

Although our findings are specific for our case-study on asparagus exports from Peru, and we should be careful to generalize results, our study entails some important policy implications. While the scientific debate on standards-as-catalysts versus standard-as-barriers to trade persists with mixed arguments and evidence, the policy discourse has largely adopted the view that private standards enhance developing countries' export performance. Our results cast doubt on the view that private standards act as a catalyst to trade and improve developing countries' export performance. This has implications for ongoing investments of NGOs and development agencies to support developing country exporters to comply with private standards and seek certification. ${ }^{14}$ Our results that private standards do not increase firms export volumes and values imply that the return to such development programs, especially in middle-income countries and in well-established export sectors, is questionable.

We urge for more research on how private standards, and food standards in general, affect the export opportunities of low- and middle-income countries. In particular, we see scope for more comparative studies, in which either-as in our research-different types of certification schemes are analyzed in one country and sector, or the effects of one specific standard are compared across countries and sectors. Such kind of comparative evidence is important to fully understand the complex interactions between standards and trade, and to come to more generally valid conclusions.

\section{NOTES}

1. The literature on food standards in developing countries focuses on how standards change the organization of supply chains (e.g., Dolan \& Humphrey, 2000; Gibbon \& Ponte, 2005) and on the welfare effects for farmers and workers (e.g., Asfaw, Mithöfer, \& Waibel, 2010; Colen, Maertens, \& Swinnen, 2012; Ehlert, Mithöfer, \& Waibel, 2014; Hansen \& Trifković, 2014; Kersting \& Wollni, 2012; Kleemann, Abdulai, \& Buss, 2014; Maertens \& Swinnen, 2009; Schuster \& Maertens, 2013; Subervie \& Vagneron, 2013).

2. Due to field logistics six of the 100 sampled companies could not be interviewed, while seven surveyed companies only exceptionally export fresh asparagus and are therefore dropped from the sample.

3. The USD was historically weak as compared to the Peruvian Nuevo Sol at the end of 2007, beginning of 2008 .

4. A National Technical Standard-NTP 209.401, dealing with hygiene practices for fresh asparagus handling was published in 2001, while NTP 209.402 dealing with Good Agricultural Practices (GAP) in asparagus was published in 2003 (Diaz, 2007).

5. Please notice that until 2011, the last year of our panel dataset, environmental and labor standards did not play a very relevant role in the entire export industry. Since then they have started to gain importance in the market of private certifications in Peru, but in this study we are considering standards focusing mainly on food quality and safety instead of environmental and social issues.

6. We report the export figure for 2003 instead of for 2001 as no company in our sample that is not certified in 2011 was already exporting in 2001 .

7. The number of variables slightly varies over the models, as time constant variables are only included in the cross-sectional model specification (simple OLS).
8. We do not recur to a "matching difference in difference" approach, as used by Henson et al. (2011) and Volpe-Martincus et al. (2010), since firms seek certification to standards in different moments between the year 2000 and 2011. The timing of certification is thus intrinsically endogenous and the long panel data dimension of our data allows us to use better methods.

9. Although the dependent variable can be binary (when considering the export dummy) or exhibit a probability mass at zero (when considering unconditional export volumes or values), we use a linear method. We do so in order to compare results with alternative estimations. Moreover, it has been shown that linear models perform as well as more complex nonlinear estimation strategies with unobservable characteristics (Bernard \& Jensen, 2004). Results from probit and tobit estimations are not reported but are very similar to the reported OLS results.

10. As proposed by Arellano and Bover (1995) the two moment conditions are combined and the lagged first-differences of the explanatory and the dependent variable are used as additional instruments to circumvent the problem that with persistent time series, the lagged levels of the explanatory and dependent variable might be weak predictors of endogenous changes (Blundell \& Bond, 1998).

11. We also estimated the System GMM model with certification as predetermined variable. These results are not reported but are very similar to the reported System GMM results with certification as endogenous variable.

12. Despite the large information on firm characteristics, the causal effect of certification would still be overestimated if certified companies are systematically better than noncertified companies along specific dimensions which are not properly controlled for in the analysis. Such a potential remaining bias resulting in overestimation does not really change our conclusion.

13. The full regression results for the OLS and fixed effects models are very similar but are not reported in order to avoid lengthy tables.

14. Initiatives such as the Pesticide Initiative Program in ACP countries (Jaud \& Cadot, 2012) and MCA or BAMEX in Madagascar (Bignebat \& Vagneron, 2011; Subervie \& Vagneron, 2013). 


\section{REFERENCES}

Anders, S., \& Caswell, J. A. (2009). Standards-as-barriers versus standards-as-catalysts: Assessing the impact of HACCP implementation on U.S. seafood imports. American Journal of Agricultural Economics, 91(2), 310-321.

Arellano, M., \& Bond, S. (1991). Some tests of specification for panel data: Monte Carlo evidence and an application to employment equations. Review of Economic Studies, 58(2), 277-297.

Arellano, M., \& Bover, O. (1995). Another look at the instrumental variables estimation of error-components models. Journal of Econometrics, 68(1), 29-51.

Asfaw, S., Mithöfer, D., \& Waibel, H. (2010). Agrifood supply chain, private-sector standards, and farmers' health: Evidence from Kenya. Agricultural Economics, 41(3-4), 251-263.

Bernard, A., \& Jensen, B. J. (1997). Exporters, skill upgrading, and the wage gap. Journal of International Economics, 42(1-2), 3-31.

Bernard, A., \& Jensen, B. J. (2004). Why some firms export. The Review of Economics and Statistics, 86(2), 561-569.

Bernard, A., Jensen, B., Redding, S., \& Schott, P. (2007). Firms in international trade. Journal of Economic Perspectives, 21(3), 105-130.

Bignebat, C. \& Vagneron, I. (2011). Cross-border coordination in the Madagascar-EU lychee chain: The role of GlobalGAP. 201106, CIRAD, INRA, Montpellier SupAgro, IRD - Montpellier, France.

Blundell, R., \& Bond, S. (1998). Initial conditions and moment restrictions in dynamic panel data models. Journal of Econometrics, 87, 115-143.

Bond, S. R. (2002). Dynamic panel data models: A guide to micro data methods and practice. Portuguese Economic Journal, 1(2), $141-162$.

Breinlich, H., \& Criscuolo, C. (2011). International trade in services: A portrait of importers and exporters. Journal of International Economics, 84(2), 188-206.

Cadot, O., Iacovone, L., Pierola, M., \& Rauch, F. (2013). Success and failure of African exporters. Journal of Development Economics, 101, $284-296$.

Chen, M., Wilson, J., \& Otsuki, T. (2008). Standards and export decisions: Firm-level evidence from developing countries. The Journal of International Trade \& Economic Development, 17(4), 501-523.

Colen, L., Maertens, M., \& Swinnen, J. (2012). Private standards, trade and poverty: GlobalGAP and horticultural employment in senegal. The World Economy, 35(8), 1073-1088.

Czubala, W., Shepherd, B., \& Wilson, J. S. (2009). Help or hindrance? The impact of harmonized standards on African exports. Journal of African Economies, 18(5), 711-744.

Darby, M., \& Karni, E. (1973). Free competition and the optimal amount of fraud. Journal of Law and Economics, 16, 67-88.

Diaz, L. (2007). Agro-industries Characterization and Appraisal: Asparagus in Peru. FAO, Agricultural Management, Marketing and Finance. Working document No. 23.

Dolan, C., \& Humphrey, J. (2000). Governance and trade in fresh vegetables: The impact of UK supermarkets on the African horticulture industry. Journal of Development Studies, 37(2), 147-176.

Ehlert, C., Mithöfer, D., \& Waibel, H. (2014). Worker welfare on Kenyan export vegetable farms. Food Policy, 46, 66-73.

Fontagné, L., Orefice, G., Piermartini, R., \& Rocha, N. (2013). Product standards and margins of trade: Firm level evidence. CESifo Working Paper Series 4169, CESifo Group Munich.

Graffham, A., Karehu, E., \& MacGregor, J. (2009). Impact of GlobalGAP on smallscale vegetable growers in Kenya. Standard bearers: Horticultural exports and private standards in Africa. London, UK: Natural Resource Institute.

Geroski, P., Machin, S., \& Van Reenen, J. (1993). The profitability of innovating firms. The RAND Journal of Economics, 24(2), 198-211.

Gibbon, P., \& Ponte, S. (2005). Trading down: Africa, value chains and the global economy. Philadelphia: Temple University Press.

Giuliani, E., Pietrobelli, C., \& Rabellotti, R. (2005). Upgrading in global value chains: Lessons from Latin American clusters. World Development, 33(4), 549-573.

Hansen, H., \& Trifković, N. (2014). Food standards are good - For middle-class farmers. World Development, 56(4), 226-242.

Helpman, E., Melitz, M., \& Rubinstein, Y. (2008). Estimating trade flows: Trading partners and trading volumes. Quarterly Journal of Economics, $123(2), 441-487$.
Henson, S. S., Masakure, O., \& Cranfield, J. (2011). Do fresh produce exporters in Sub-Saharan Africa benefit from GlobalGAP certification? World Development, 39(3), 375-386.

Henson, S., \& Humphrey, J. (2010). Understanding the complexities of private standards in global agri-food chains as they impact developing countries. Journal of Development Studies, 46(9), 1628-1646.

Hoekman, B., \& Nicita, A. (2011). Trade policy, trade costs, and developing country trade. World Development, 39(12), 2069-2079.

Honda, K., Otsuki, T., \& Wilson, J. S. (in press). Food safety standards and international trade: the impact on developing countries' export performance. In Hammoudi, A., Grazia C., Surry, Y. \& Traversac, J. -B. (Eds.) Food safety, market organization, trade and development. Springer.

Hudson, J., \& Jones, P. (2003). International trade in 'Quality Goods': Signaling problems for developing countries. Journal of International Development, 15, 999-1013.

Jaffee, S. \& Henson, S. (2004). Standards and agro-food exports from developing countries: Rebalancing the debate. World Bank Policy Research Working Paper No. 3348.

Jaffee, S., \& Masakure, O. (2005). Strategic use of private standards to enhance international competitiveness: Vegetable exports from Kenya and elsewhere. Food Policy, 30(3), 316-333.

Jaud, M., \& Cadot, O. (2012). A second look at the pesticides initiative program: Evidence from Senegal. World Trade Review, 11(03), 490-506.

Kersting, S., \& Wollni, M. (2012). New institutional arrangements and standard adoption: Evidence from small-scale fruit and vegetable farmers in Thailand. Food Policy, 37(4), 452-462.

Kleemann, L., Abdulai, A., \& Buss, M. (2014). Certification and access to export markets: Adoption and return on investment of organic-certified pineapple farming in Ghana. World Development, 64(12), 79-92.

Maertens, M., \& Swinnen, J. (2007). Standards as barriers and catalysts for trade and poverty reduction. Journal of International Agricultural Trade and Development, 4(1), 47-61.

Maertens, M., \& Swinnen, J. (2009). Trade, standards and poverty: Evidence from Senegal. World Development, 37(1), 161-178.

Maertens, M., Minten, B., \& Swinnen, J. (2012). Modern food supply chains and development: Evidence from horticulture export sectors in Sub-Saharan Africa. Development Policy Review, 30(4), 473-497.

Maskus, K., Otsuki, T., \& Wilson, J. S. (2013). Do foreign product standards matter? Impacts on costs for developing country exporters. Asia-Pacific Journal of Accounting and Economics, 20(1), 37-57.

Melitz, M. J. (2003). The impact of trade on intra-industry reallocations and aggregate industry productivity. Econometrica, 71(6), 1695-1725.

Melo, O., Engler, A., Nahuehual, L., Cofre, G., \& Barrena, J. (2014). Do sanitary, phytosanitary, and quality-related standards affect international trade? Evidence from Chilean fruit exports. World Development, $54,350-359$.

Nelson, P. (1970). Information and consumer behaviour. Journal of Political Economy, 78(2), 311-329.

Nickell, S. J. (1981). Biases in dynamic models with fixed effects. Econometrica, 49(6), 1417-1426.

O'Brien, T. M., \& Diaz, A. (2004). Mejorando la competitividad y el acceso a los mercados de exportaciones agrícolas por medio del desarrollo y aplicación de normas de inocuidad y calidad: El ejemplo del espárrago Peruano. Instituto Interamericano de Cooperación para la Agricultura (IICA).

Otsuki, T. (2011). Effect of international standards certification on firmlevel exports: An application of the control function approach. The Empirical Economics Letters, 10(7).

Roberts, M., \& Tybout, J. (1997). The decision to export in Colombia: An empirical model of entry with sunk costs. American Economic Review, 87(4), 545-564.

Roodman, D. (2007). How to Do xtabond2: An introduction to "Difference" and "System" GMM in Stata. Working Paper, No. 103, Center for Global Development.

Roodman, D. (2009). A note on the theme of too many instruments. Oxford Bulletin of Economics and Statistics, 71(1), 135-158.

Schuster, M., \& Maertens, M. (2013). Do private standards create exclusive supply chains? New Evidence from the Peruvian asparagus export sector. Food Policy, 43, 291-305. 
Shepherd, B., \& Wilson, N. (2013). Product standards and developing country agricultural exports: The case of the European Union. Food Policy, 42, 1-10.

Shimizu, T. (2006). Expansion of asparagus production and export in Peru. Discussion Paper No. 73, Institute of Developing Economies.

Subervie, J., \& Vagneron, I. (2013). A drop of water in the Indian Ocean? The impact of GlobalGAP certification on Lycee farmers in Madagascar. World Development, 50, 57-73.

Tran, N., Wilson, N.. \& Anders, S. (2012). Standard harmonization as chasing zero (tolerance limits): The impact of veterinary drug residue standards on crustacean imports in the EU, Japan, and North America. American Journal of Agricultural Economics, 94(2), 496-502.

Volpe-Martincus, C., Castresana, S., \& Castagnino, T. (2010). ISO standards: A certificate to expand exports? Firm-Level evidence from Argentina. Review of International Economics, 18(5), 896-912.
Wilson, J., \& Otsuki, T. (2003). Food safety and trade: Winners and losers in a non-harmonized world. Journal of Economic Integration, 18(2), 266-287.

Wilson, J., Otsuki, T., \& Majumdar, B. (2003). Balancing food safety and risk: Do drug residue limits affect international trade in beef? Journal of International Trade and Economic Development, 12(4), 377-402.

Wilson, J., Mann, C. L., \& Otsuki, T. (2003). Trade facilitation and economic development: A new approach to quantifying the impact. World Bank Economic Review, 17(3), 367-389.

Windmeijer, F. (2005). A finite sample correction for the variance of linear efficient two step GMM estimates. Journal of Econometrics, 126(1), $25-51$.

Xiong, B., \& Beghin, J. (2013). Does European aflatoxin regulation hurt groundnut exporters from Africa? European Review of Agricultural Economics, 40(5), 895.

Available online at www.sciencedirect.com

\section{ScienceDirect}

